\title{
RICEBEAN IN HOME GARDENS OF THE CHITWAN VALLEY
}

\author{
Kamal Khadka ${ }^{1}$ and Aditya R. Khanal ${ }^{1}$
}

\begin{abstract}
Ricebean is a neglected and underutilized grain legume grown in specific pockets by poor and marginal farmers. Despite being a multipurpose legume, its use in food, fodder and green manure crop were limited to farmers' knowledge. Recognizing multiple use of ricebean a reconnaissance survey was conducted in Chitwan valley to assess the potential of ricebean as one of the home garden species in December 2007. Household survey was done to appraise the knowledge on ricebaean and its use. Agro-morphological traits were analysed. The study showed ricebean to be a new crop in the valley. Rice bean is helping the farmers to diversify their diet. Ricebean is also a good source of fodder and farmers believe that ricebean enriches soil fertility in the home gardens. Descriptive analysis of the agro-morphological traits showed diversity in the ricebean accessions grown by the farmers. The study clearly indicated that ricebean can be a potential crop in the home gardens of the Chitwan valley.
\end{abstract}

Key words: Home garden, diversity in diet, ricebean, soil fertility

\section{BACKGROUND}

Home gardens are fundamental components of traditional Nepalese farming systems. Typical home gardens consist of a family rearing diverse plant and animal species in their homestead for home consumption. Home gardens possess a high level of species and varietal diversity (Gautam et. al., 2004). Home gardens in Nepal have multiple uses: as a source of livelihood, firewood and timber, spices and medicinal plants, green manure and pesticides (Regmi et. al., 2004). Biodiversity that has an immediate value is maintained in home gardens (Sthapit et. al., 2004) and they are important for the in situ conservation of a wide range of unique genetic resources for food and agriculture (Subedi et. al., 2004). This clearly specifies that home gardens preserve numerous neglected and underutilized species.

Home gardens play a vital role in improving family nutrition. Diverse types of vegetables, fruits and domestic animals which form the major gears of home gardens play key role in maintain the health of the family members. The fact urges that home gardens should posses a maximum possible diversity in terms of crops and animals such that a family is never deprived from having a nutrient rich diet. Promotion of local, neglected and underutilized species in home gardens fulfils the requirements of family nutrition through enhanced species diversity.

Ricebean (Vigna umbellate (Thumb) Ohio and Ohasi) is a neglected and underutilized grain legume grown in specific pockets by poor and marginal farmers

\footnotetext{
${ }^{1}$ Local Initiatives for Biodiversity, Research and Development (LI-BIRD), Pokhara, P.O. Box 324, Pokhara, Nepal
} 
(Neupane, 2003). It is principally grown as an intercrop with maize or millet, on rice bunds, and margins of bari land mainly for dried pulse in the hill areas of Nepal. Very few farmers grow ricebean in their homestead as it receives no attention as an important component in home gardens. Ricebean is a multipurpose legume as it values as a food, fodder and green manure crop. The seeds of ricebean are good sources of carbohydrates, proteins, minerals and vitamins. Protein in ricebean is rich in limiting amino acids methionine and trytophan (Carvalho and Vieira 1996). Many people in Nepal are undernourished. When searching for a solution to malnutrition in Nepal, the most common misconception is that it stems entirely from lack of food security and cannot be reduced unless general poverty is addressed first (Atwood, 2007). Poverty and insufficient food are a part of the problem in this context but poor feeding practice is the major cause behind this severity. Ricebean can be one of the options for improving the cereal based diet. In addition, the levels of thiamine, niacin, riboflavin, folate and pantothenic acid are high, and it provides sizable amounts of important minerals such as $\mathrm{Ca}, \mathrm{P}, \mathrm{Mg}, \mathrm{K}, \mathrm{Fe}, \mathrm{Zn}, \mathrm{Cu}$ and $\mathrm{Mn}$ (Anderson, 2009). Its foliage and dry straw are valuable livestock feed, and when used as a green manure it improves soil fertility.

Ricebean is a crop grown commonly in the hills of Nepal but also grows well in the lower altitudes. Through some informal sources it was known that some of the farmers in the Chitwan valley were growing ricebean in their home gardens. Valuing its multiple uses, ricebean can be an additional source of food and nutrition. Ricebean can serve as an important component of family diet if it is grown by the farmers in their home gardens. Considering this fact, a reconnaissance survey was conducted in Chitwan valley to assess the potential of ricebean as one of the home garden crop species.

\section{METHODOLOGY}

There was no any documented information on ricebean cultivation in Chitwan valley. Based on information supplied by some local people, a reconnaissance survey was designed to assess ricebean diversity and farmers perception on this crop in the Chitwan valley. The questionnaires were developed to appraise the knowledge on ricebean and its use in the valley. Survey was conducted in 33 households from nine Village Development Committees viz. Gitanagar, Chainpur, Pithuwa, Jutepani, Padampur, Sharadanagar, Gunjanagar, Divyanagar and Meghauli; and Bharatpur Municipality of Chitwan valley in December 2007. The agro-morphological traits were also recorded during the survey. Analysis of the survey data and the descriptive analysis of the agro-morphological data were done using SPSS 11.5 while figures were developed using Microsoft Excel 2007. 


\section{RESULTS AND DISCUSSIONS}

During the study, it was observed that most of the farmers cultivated ricebean at the fence in front of the house and a few farmers planted the crop at the backyard where the land was unusable for any other purposes and in wasted land at the embankment of irrigation canals. The plants were trained along the fence in most of the home gardens and in others the plants were found trailing in the trees available at the edges of home gardens. Very few farmers were aware in providing stakes so that the ricebean plants could grow properly.

\section{SOURCE OF GERMPLASM}

The results obtained from the exploration of ricebean in the home gardens of Chitwan valley showed that there is increasing trend in growing ricebean in the homestead. It was found that the farmers received ricebean seeds from their close relatives in the western mid hill districts like Gorkha, Tanahun, Lamjung, Kaski, Syangja etc (Figure 1). According to the result 12 farmers received seed from Gorkha. Similarly, 5 farmers from received seed from Tanahun while Lamjung and Kaski districts sources for four farmers each. Only 2 farmers received from Syangja and the remaining 6 farmers did not know the source as they borrowed the seeds from their neighbours. When the farmers migrated from hills to Chitwan valley, probably they did not bring any seeds along with them. But in the following years their relative must have sent or provided ricebean seeds to them during family visits. It was also observed that these farmers have been supplying the seeds to their neighbours indicating the seed spread through farmer to farmer network.

Ricebean cultivation in the home gardens is not very common in the mid hills. But ricebean is a long duration crop and farming practice in the Chitwan valley does not allow the farmers to cultivate ricebean in the main field extensively. Since no crop improvement has been initiated in this crop. Farmers are compelled to grow only the landraces available. On these grounds, farmers are growing ricebean in the home gardens merely for home consumption.

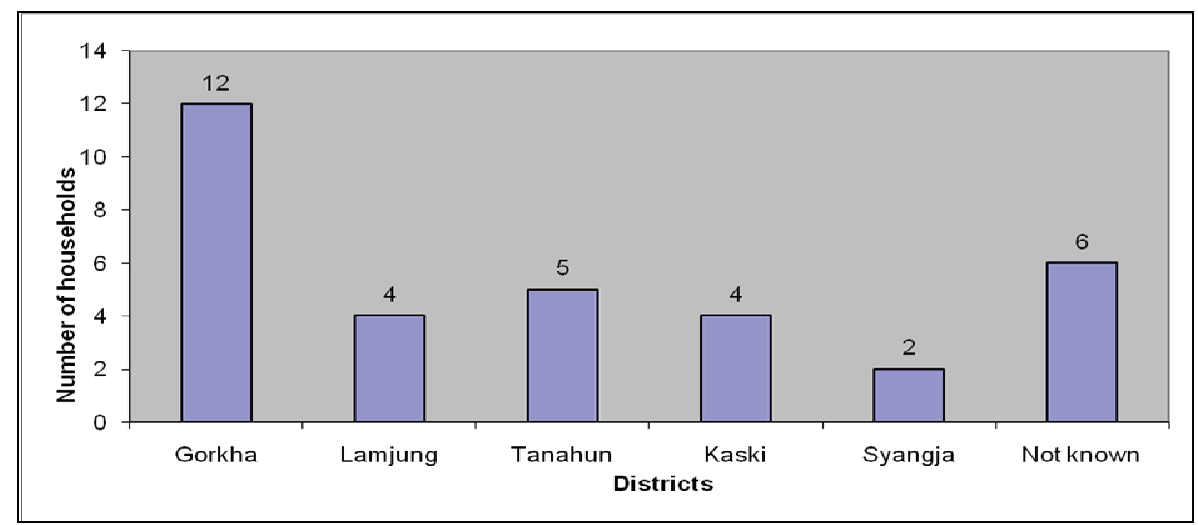

Figure 1. Source of ricebean seeds in the home gardens of Chitwan valley 
The result of the study exhibited that farmers in the Chitwan valley are new to ricebean cultivation with $32 \%$ of them cultivating ricebean for only 1 to 3 years followed by $26 \%$ of the farmers cultivating for only 3 to 5 years (Figure 2 ). It was found that $21 \%$ of them were growing ricebean for the first time. This is a comprehensible indication that ricebean is a new crop in Chitwan valley. The Chitwan valley is known way ahead in commercial farming and since, no genetic improvement has been done in ricebean, varieties suitable to Chitwan conditions are not available. Still there is increasing trend of cultivation of ricebean and it is leading to increased diversity in the home gardens.

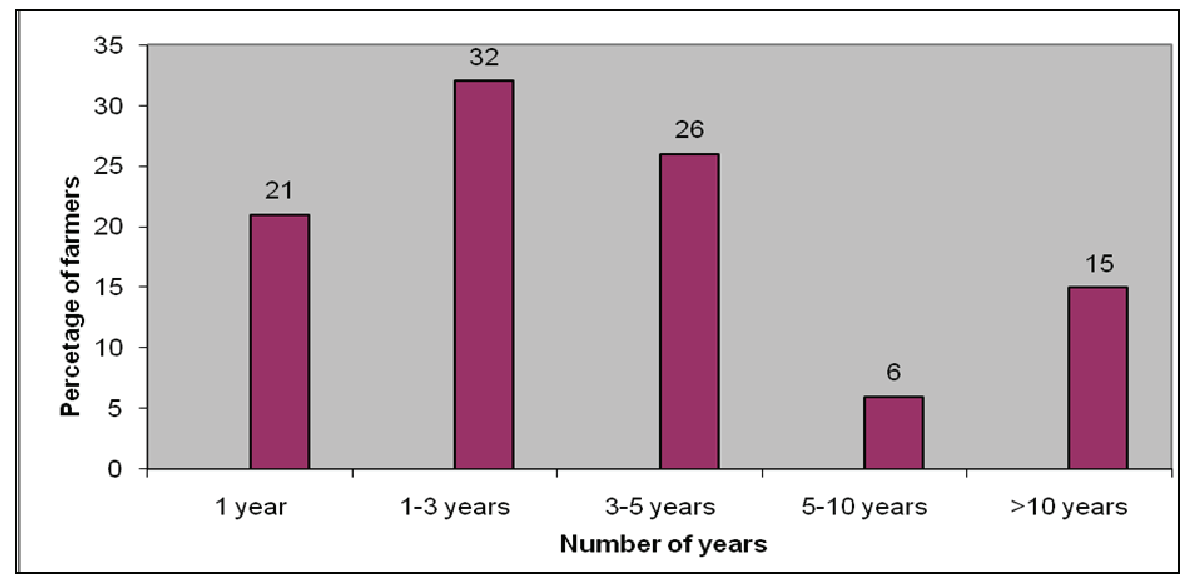

Figure 2. Distribution of farmers by the number of years of ricebean cultivation in Chitwan valley

\section{USES OF RICEBEAN IN THE CHITWAN VALLEY}

Farmers consider ricebean as one of the crops with multiple uses. Some farmers used ricebean only for single purpose while others used it for multiple purposes. Hence, there were altogether 108 responses on the use of ricebean from 33 farmers. Farmers mainly indicated the use of ricebean grains in various forms. The result exhibited that $29.6 \%$ of responses were on the use of green beans as vegetable (Figure 3). Similarly, $28.7 \%$ responses were on use of ricebean as whole grain Dal, $25.9 \%$ responses were on Biramla, and $8.3 \%$ on splitted grains as Dal. Farmers in the mid hills prepare a number of recipes ${ }^{1}$ like Dal, Batuk, Biramla, Rot, Kwati etc. from dried grains of ricebean. But in the Chitwan valley, diversity in terms of recipes prepared from ricebean was found less.

The result also specified that $3.7 \%$ of the responses from the farmers were on use of ricebean as fodder. Farmers use foliage and dried straw of ricebean as fodder.

\footnotetext{
${ }^{1} \mathrm{Dal}$ is the soup prepared from legumes. Biramla is prepared by soaked beans of ricebean. Batuk, and Rot are local recipes prepared using ricebean flour. Kwati is a recipe prepared using mixture of whole grains of number of beans.
} 
It was found that the farmers were aware of the fact that ricebean fodder is highly palatable and nutritious to farm animals. Remaining $3.7 \%$ of the famers believed that ricebean amends soil fertility and it is suitable for the marginal land where they grow ricebean for a year becomes suitable for growing other exhaustive crop the following year.

It was assessed that the first use of ricebean by the farmers of Chitwan valley was to use the green beans as vegetable. More than $67 \%$ of the farmers mixed green beans with potato and other vegetables and $21 \%$ used ricebean to prepare whole grain Dal (Figure 4). This result contrasts in a great extend compared with the main use of ricebean in other ricebean growing regions where Dal is the major recipe prepared and Batuk, Bara and Biramla form the principle snack. But as ricebean is grown in homestead only, farmers in Chitwan valley have started consuming green beans of ricebean as vegetable.

The price of the majority of the popular pulses is very high compared to that of ricebean. This is a good sign that farmers are including an easy and cheap source of protein in the home gardens. Growing ricebean in home gardens may not give surplus yield to use the grains as Dal/soup, but use of green beans as vegetables can supply enough protein to a family. While considering the economically poor communities, ricebean is especially well suited both as an alternative to, and as a supplement to scarce animal source foods.

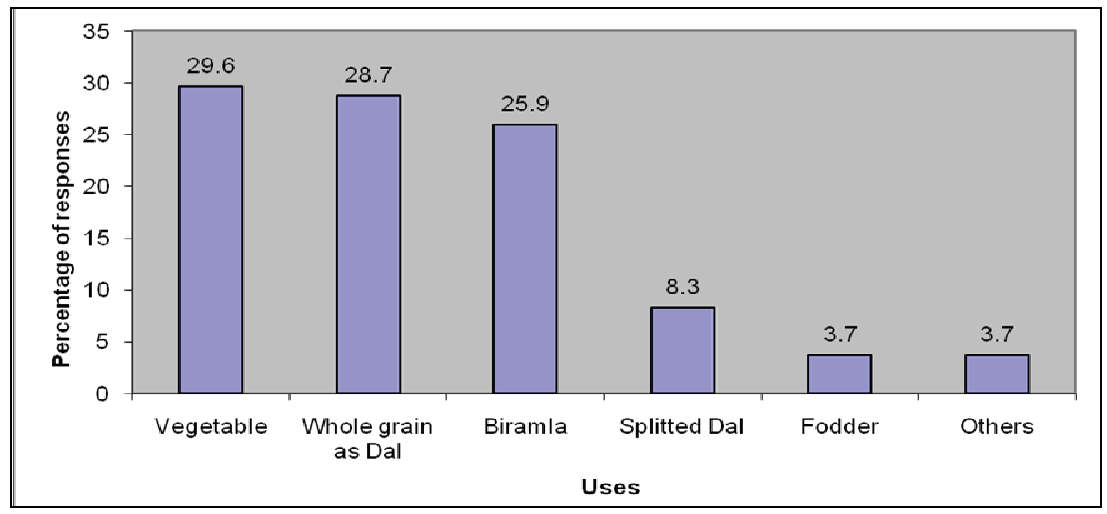

Figure 3. Uses of ricebean in Chitwan valley

\section{FARMERS PREFERRED TRAITS OF RICEBEAN}

The study showed that most of the traits preferred by the farmers were common among the farmers. According to the result, 79\% farmers preferred ricebean plants with indeterminate growth habit compared to the determinate types while $85 \%$ preferred bold seeded ricebean. In addition to that,73\% farmers considered long pods (73\%), high yield (76\%) and good cooking quality (48\%) as the preferred traits of ricebean. Farmers were indifferent to yellowish and mottled colored seeds but they disliked red colored ricebean compared to yellow and mottled grains. According to the respondent farmers Dal prepared from red coloured grains gives off taste. 
There is a rationale behind farmers' preference for indeterminate landraces: they require multiple picking and farmers can harvest green beans of ricebean for vegetable for more than a month from a single plant. Farmers prefer bold seeded landraces due to ease in splitting pods for extracting green beans for vegetables but large seeds suit better for vegetables compared to smaller beans. On the other hand large seeds are suitable for preparing local snacks as Biramla too.

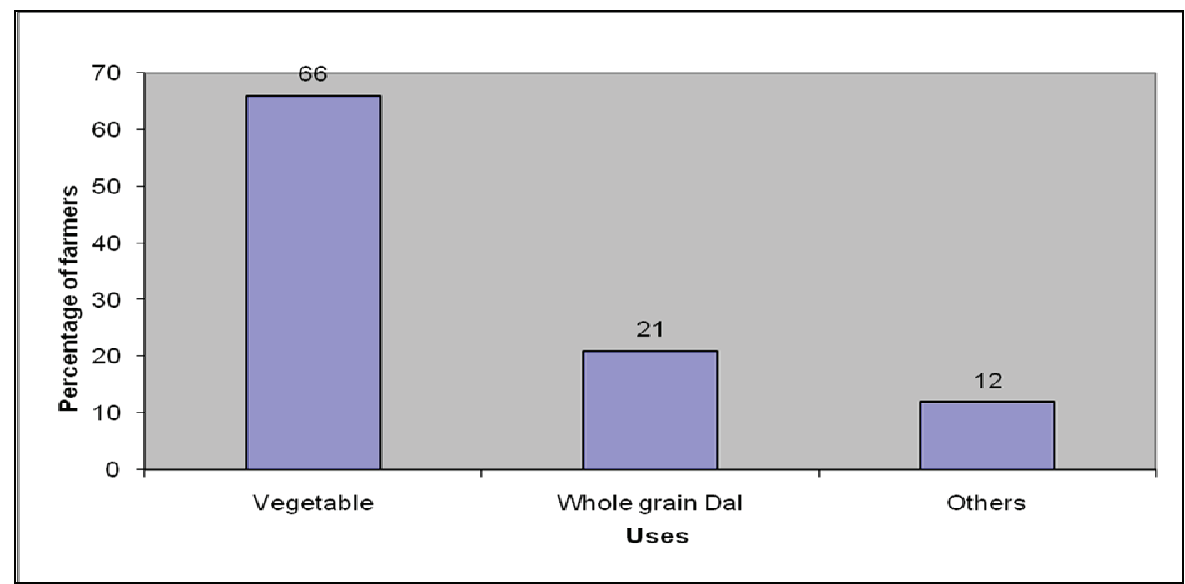

Figure 4. First use of ricebean in Chitwan valley

\section{AESTHETIC VALUE OF RICEBEAN}

The result showed that $27 \%$ farmers valued ricebean as one of the crops with aesthetic values. Ricebean does not necessitate a great care as other crops need. It grows well in marginal and wasted land. Thus, farmers have opportunity to utilize their waste land to convert into wealth land. In the Chitwan valley, the fence around their house is the best place for them to cultivate ricebean. Ricebean being an indeterminate crop its flowering duration lasts for almost one month. The trees and the poles in the fence stake the ricebean vines in such a way that the large ricebean vines with yellow flowers along the fence give good aesthetic value for the farmers' homestead.

\section{DIVERSITY OF RICEBEAN IN THE CHITWAN VALLEY}

The result showed that the ricebean accessions did not vary much for traits like leaflet length, leaflet width, number of pods per peduncle, number of seeds per pod, pod length etc (Table 1). High variation in thousand grains was observed which was mainly due to the difference in seed size of the accessions. Seed size is one of the yield attributing traits. The result clearly specified that the farmers are growing diverse types of ricebean accessions in the home gardens. 
Table 1. Descriptive analysis of some of the quantitative traits of ricebean in the Chitwan valley

\begin{tabular}{lllll}
\hline Quantitative traits & Mean & Range & Standard deviation & $\begin{array}{l}\text { Coefficient of } \\
\text { variation }\end{array}$ \\
\hline Leaflet length $(\mathrm{cm})$ & 11.1 & $7.1-13.4$ & 1.38 & 12.35 \\
Leaflet width & 8.2 & $4.9-10.5$ & 1.26 & 15.44 \\
$\begin{array}{l}\text { Number of pods per } \\
\text { peduncle }\end{array}$ & 4.3 & $3.0-6.6$ & 0.85 & 19.60 \\
Number of seeds per pod & 8.1 & $6.8-9.4$ & 0.62 & 7.69 \\
Pod length $(\mathrm{cm})$ & 10.8 & $6.7-13.1$ & 1.61 & 14.95 \\
1000 grain weight $(\mathrm{g})$ & 145.9 & $39.0-255.6$ & 58.8 & 40.28 \\
\hline
\end{tabular}

\section{CONCLUSIONS}

In the Chitwan valley farmers are growing ricebean in their home gardens in the recent few years. The study clearly showed that source of the ricebean germplasms in the Chitwan valley are mainly Gorkha, Tanahun, Lamjung, Kaski and Syanja districts. Farmers are consuming ricebean as vegetable, Dal and Biramla. Ricebean in the home gardens of the Chitwan valley are not only used as food and fodder these are also adding aesthetic value to the homestead. There are no commercial varieties of ricebean available as no breeding has been initiated in this crop. In this set-up bold seeded indeterminate varieties which are tall with luxuriant vegetative growth and that allow multiple picking suitable to the home gardens can be supplied to the farmers. Ricebean being a crop that requires less inputs, care and management it adds no extra load to the family members. Diversity in terms of various agro-morphological traits was also observed among the accessions grown by the farmers. These facts establish that ricebean has potential to be one of major home garden species of Chitwan valley in the future.

\section{REFERENCES}

Anderson P., 2009. Nutritional qualities of ricebean. Report from the project FOSRIN (Food Security through Ricebean Researh in India and Nepal). University of Bergen, Norway.

Atwood, T., 2007. Malnutrition is severe in Nepal: Indicating continued poverty and backwardness for decades to come. The Kathmandu Post, published in August 9, 2007 edition.

Carvalho N.M. de and R.D. Vieria, 1996. Ricebean (Vigna umbellate (Thumb.) Ohwi et Ohashi). In: E. Nkowolo and J. Smartt (eds). Legumes and oilseeds in nutrition. Chapman and Hall. pp: 222-228.

Gautam R, R. Suwal and B. Sthapit, 2004. Assessment of dietary diversity: A basis for promoting plant genetic species in home gardens. Paper presented at the Second National Sharing and Learning Workshop of Home gardens in Pokhara Nepal, 6-7 August 2004, LI-BIRD, Nepal. 
Neupane R.K., 2003. Present scenario of winter grain legumes research in Nepal In: R.K. Neupane and N.P. Khanal (eds). Proceedings of the $25^{\text {th }}$ National Winter Crops Workshop (grain legumes). Nepal Agricultural Research Council, Khumaltar, Lalitpur. 11-12 September, 2002. pp: 1-9.

Regmi B, K. Aryal, B. Tamang and P. Shrestha, 2004. Home gardens: An opportunity to minimize pressure on slash and burn system and option for improving dietary diversity of Chepang households. Paper presented at the Second National Sharing and Learning Workshop of Home gardens in Pokhara Nepal, 6-7 August 2004, LI-BIRD, Nepal.

Sthapit B, R. Gautam and P. Eyzaguirre, 2004. The value of home gardens to small farmers. Paper presented at the Second National Sharing and Learning Workshop of Home gardens in Pokhara Nepal, 6-7 August 2004, LI-BIRD, Nepal.

Subedi A, R. Gautam, R. Suwal, P. Shrestha, B. Sthapit, 2004. Plant diversity in home gardens in Nepal. Paper presented at the Second National Sharing and Learning Workshop of Home gardens in Pokhara Nepal, 6-7 August 2004, LI-BIRD, Nepal. 